\title{
Monitoring Current-Season Spread of Potato virus $Y$ in Potato Fields Using ELISA and Real-Time RT-PCR
}

\author{
Manphool S. Fageria and Mathuresh Singh, Agricultural Certification Services, Fredericton, NB, Canada E3B 8B7; Upeksha \\ Nanayakkara, Yvan Pelletier, and Xianzhou Nie, Potato Research Centre, Agriculture and Agri-Food Canada, Fredericton, NB, Can- \\ ada E3B 4Z7; and David Wattie, New Brunswick Department of Agriculture, Aquaculture and Fisheries, Wicklow, NB, Canada E7L 3S4
}

\begin{abstract}
Fageria, M. S., Singh, M., Nanayakkara, U., Pelletier, Y., Nie, X., and Wattie, D. 2013. Monitoring current-season spread of Potato virus Y in potato fields using ELISA and real-time RT-PCR. Plant Dis. 97:641-644.

The current-season spread of Potato virus $Y$ (PVY) was investigated in New Brunswick, Canada, in 11 potato fields planted with six different cultivars in 2009 and 2010. In all, 100 plants selected from each field were monitored for current-season PVY infections using enzymelinked immunosorbent assay (ELISA) and real-time reverse-transcription polymerase chain reaction (RT-PCR) assay. Average PVY incidence in fields increased from $0.6 \%$ in 2009 and $2 \%$ in 2010 in the leaves to $20.3 \%$ in 2009 and $21.9 \%$ in 2010 in the tubers at the time of harvest. In individual fields, PVY incidence in tubers reached as high as $37 \%$ in 2009 and $39 \%$ in 2010 at the time of harvest. Real-time RT-

PCR assay detected more samples with PVY from leaves than did ELISA. A higher number of positive samples was also detected with real-time RT-PCR from growing tubers compared with the leaves collected from the same plant at the same sampling time. PVY incidence determined from the growing tubers showed a significant positive correlation with the PVY incidence of tubers after harvest. Preharvest testing provides another option to growers to either top-kill the crop immediately to secure the seed market when the PVY incidence is low or leave the tubers to develop further for table or processing purposes when incidence of PVY is high.
\end{abstract}

In recent years, increases in Potato virus $Y$ (PVY) incidence in potato fields across North America have been observed by potato growers and researchers $(6,8,13)$. As a consequence, PVY has become a serious concern for the seed potato industry, and the rejection of seed lots submitted for certification is not uncommon (10). $\mathrm{PVY}^{\mathrm{O}}$ is the most prevalent strain in New Brunswick, Canada. Other emerging strains in the province include the tobacco veinal necrosis strain $\left(\mathrm{PVY}^{\mathrm{N}}\right)$, potato tuber necrosis strain $\left(\mathrm{PVY} \mathrm{Y}^{\mathrm{NTN}}\right)$, and recombinant $\mathrm{N}: \mathrm{O}$ strain $\left(\mathrm{PVY}^{\mathrm{N}: \mathrm{O}}\right.$ or $\left.\mathrm{PVY}^{\mathrm{N}-\mathrm{Wi}}\right)(12)$. The practical way to manage PVY is by testing for the whole complex of PVY regardless of the strain group and using seed potato with minimum PVY content (8). One of the major challenges seed potato growers in New Brunswick and other jurisdictions facing is current-season spread of PVY within and between fields by aphids (8). This PVY spread can be effectively managed by planting virus-free seed potato and reducing current-season spread of PVY by using appropriate crop management practices, particularly applications of mineral oil $(2,4)$ and combined applications of mineral oil and insecticides (9).

Different methods are currently used to detect the presence of PVY. Testing of tubers is traditionally performed using grow-out tests where plants are observed for symptoms in symptom-producing cultivars (17). The grow-out observation in symptomless cultivars is usually supplemented with enzyme-linked immunosorbent assay (ELISA) testing of leaves. However, the grow-out test takes approximately 6 to 8 weeks to perform and growers loose early market opportunities for sale. Moreover, studies have shown that detection of PVY by ELISA is not reliable in dormant tubers $(5,18)$. However, ELISA and real-time reverse-transcription polymerase chain reaction (RT-PCR) assay have been shown to have comparable rates of detection in tubers up to 10 weeks after harvest (7). PCR-based methods have been successfully used to

Corresponding author: M. Singh, E-mail: msingh@ potatoesnb.com

Accepted for publication 4 December 2012.

http://dx.doi.org/10.1094/PDIS-03-12-0283-RE

(C) 2013 The American Phytopathological Society detect PVY from leaves, sprouts, and dormant tubers $(1,3,19)$. If testing could be conducted on developing tubers, seed and tablestock potato growers would be able to make more knowledgeable decisions on timing of harvest to take advantage of available markets. When the intended seed crop is found to have a low incidence of PVY, the decision can be made by seed potato growers to top-kill as soon as tubers attained suitable size for seed purposes, to secure the seed market. Similarly, the crop can be left for further tuber development for table or processing purposes when the PVY incidence is high, provided the producer is a seed and table-stock grower.

ELISA- and PCR-based methods have not been used to determine the current-season spread of PVY in potato fields except for the preliminary work conducted by Singh et al. (21). Therefore, the main objective of this study was to monitor the current-season spread of PVY in the potato-growing areas of New Brunswick. We used real-time RT-PCR and ELISA to determine whether preharvest testing of leaves and developing tubers can accurately predict the PVY incidence of tubers at harvest.

\section{Materials and Methods}

Selection of fields and cultivars. In all, 11 seed potato fields, including one field of 'Adirondack Red' and two fields each of 'CalWhite', 'Goldrush', 'Innovator', 'Russet Burbank', and 'Shepody', were selected to determine the current-season spread of PVY in 2009 and 2010. Field size varied from 2.2 to 48.6 ha in 2009 and 3 to 38 ha in 2010. The fields were distributed across the major potato-growing areas in Florenceville and Grand Falls, New Brunswick. All growers followed crop rotations, rogueing, and early topkilling. However, number and time of spray of mineral oil and insecticides varied among the fields. In total, 120 potato plants were randomly selected from six rows (20 plants/row, and plants approximately $6 \mathrm{~m}$ apart within the row) and flagged along a transect 4 to 5 weeks after planting. Plants were selected from every fourth row for better representation of the field. Approximately $2,600 \mathrm{~m}^{2}$ from a single corner of each field was selected for the location of transect. Two leaves from each plant were collected during the week of 22 June in both 2009 and 2010. The leaves were tested for PVY using ELISA to estimate the initial disease incidence (seedborne) of the field. Based on the results of this test, 
100 PVY-free plants were chosen from the 120 tested plants from each field to monitor the current-season spread of PVY throughout the growing season. Leaf samples were collected again in the week of 20 July and the week of 17 August to test for the presence of PVY using ELISA and real-time RT-PCR. Two developing tubers were also collected from each plant in the week of 17 August, 12 to 14 days before top-kill, and tested for the presence of PVY using the real-time RT-PCR assay (18). Two tubers were collected again at the end of the growing season (the week of 6 September) after the plants were top-killed and tested for the presence of PVY using the real-time RT-PCR assay. The tubers were then planted in a greenhouse after breaking dormancy (11) to conduct the grow-out test. The greenhouses were maintained at $12 \mathrm{~h} \mathrm{light/day}\left(90 \mu \mathrm{m}^{2} / \mathrm{s}\right)$ at 22 to $25^{\circ} \mathrm{C}$. Leaves collected from the greenhouse-grown tubers were tested for the presence of PVY using ELISA. Growers submitted tubers from the same field (200 tubers/field) to the Canadian Food Inspection Agency (CFIA)-approved laboratory for PVY testing, where the tubers were sprouted and tested using ELISA. These results were also compared with the results from our tuber study.

Determination of PVY infection level in postharvest tubers based on preharvest testing. Developing tubers can be tested at least 2 weeks before the tops are killed by spraying herbicide prior to harvest. The PVY level in developing tubers and at harvest were assessed using real-time RT-PCR to determine whether there was any association between PVY incidence at these two assessment times. Developing tubers and tubers at harvest were tested during the weeks of 17 August and 6 September, respectively. Logistical regression and correlation coefficients were determined between PVY incidence of developing tubers and PVY incidence at the time of harvest.

ELISA. All leaf samples collected were tested for PVY using the double-antibody sandwich ELISA. Serotype-nonspecific polyclonal antibody (Phyto-Diagnostics) was used as described previously by Singh et al. (20). Polystyrene microtiter plates (Sarstedt, Ag. and Co.) were first coated with a polyclonal/capture antibody. Leaf sap extracted using a roller press (Meku) was diluted (1:1 volume) with a conjugate buffer $\left(50 \mathrm{ml}\right.$ of $1 \mathrm{M} \mathrm{KPO}_{4}[\mathrm{pH} 7.4], 8.0$ $\mathrm{g}$ of $\mathrm{NaCl}, 20.0 \mathrm{~g}$ of polyvinylpyrrolidone (PVP), $3.0 \mathrm{~g}$ of skim milk powder, and $0.5 \mathrm{ml}$ of Tween 20 per liter) and $100 \mu$ of the leaf sap was then added to each well on the plate. Fresh leaf tissues from plants maintained in the greenhouse were used as PVYpositive and -negative controls and were added to each plate. Also, a buffer control was included on each plate. The plates were incubated for overnight at $4^{\circ} \mathrm{C}$, washed three times using a plate washer (Meku) with double distilled water, and then dried by tapping the inverted plates on absorbent paper to remove excess water. The conjugated antibody (monoclonal) was diluted in conjugate buffer and $100 \mu \mathrm{l}$ of diluted antibody was added to each well and incubated for $4 \mathrm{~h}$ and $30 \mathrm{~min}$ at $37^{\circ} \mathrm{C}$. The plates were washed and dried again before adding $100 \mu \mathrm{l}$ of ELISA substrate buffer (diethanolamine at $97 \mathrm{ml} / \mathrm{liter}, \mathrm{pH} 9.8$ ) containing $5.0 \mathrm{mg}$ of $p$-nitrophenyl phosphate per $10 \mathrm{ml}$ of buffer in each well of the plate. The plates were kept at room temperature for $1 \mathrm{~h}$ and absorbance was measured at $405 \mathrm{~nm}$ (Multiskan Ascent; Thermo Labsystems). The background absorbance was automatically subtracted using buffer wells before positive and negative threshold values were calculated. A sample was considered positive when the absorbance was greater than three times the average value of the fresh negative control (18).

Real-time RT-PCR. Total RNA was extracted from all leaves (with the exception of the initial collection in the growing season) and tubers (two tubers collected before and two after top-kill) using the TRI-Reagent (Molecular Research Center, Inc.) following the manufacturer's instructions. Complementary DNA was synthesized as described previously by Nie and Singh (14). The real-time RT-PCR assay was performed using the following primers: forward-5'CCA ATC GTT GAG AAT GCA AAA C3', reverse-5'ATA TAC GCT TCT GCA ACA TCT GAG A3', and the probe-6FAM-5'TTA GGC AAA TCA TGG CAC AT3'-MGBNFQ (Applied Biosystems Inc. [ABI]). The master mix (12.5 $\mu \mathrm{l}$ ) (part number 4318157; ABI) was mixed with $0.2 \mu \mathrm{l}$ of each of the forward and reverse primers $(400 \mathrm{nM}), 0.5 \mu \mathrm{l}$ of TaqMan probe (150 $\mathrm{nM}), 9.1 \mu \mathrm{l}$ of nuclease-free water, and $2.5 \mu \mathrm{l}$ of cDNA to make a final volume of $25 \mu \mathrm{l}$. Amplification was performed in an ABI PRISM 7700 Sequence Detector. The PCR was initiated for $2 \mathrm{~min}$ at $50^{\circ} \mathrm{C}$ to activate the AmpErase UNG followed by $10 \mathrm{~min}$ at $95^{\circ} \mathrm{C}$. This was followed by 35 cycles of $15 \mathrm{~s}$ at $95^{\circ} \mathrm{C}$ and $1 \mathrm{~min}$ at $50^{\circ} \mathrm{C}$. Reactions without templates served as the negative control. The starting amount of a specific mRNA in unknown sample was determined. The standard curve was produced based on the linear relationship between the cycle threshold $(\mathrm{Ct})$ value and logarithm of the starting quantity of mRNA. The Sequence Detection System Software (version 1.6.3; ABI) was used to quantify the unknown samples. The software produces the $\mathrm{Ct}$ value for each sample and quantifies the amount of the target using the standard curve. The amount of the target was then normalized to the reference (22).

Table 1. Potato virus Y (PVY) incidence (\%) in potato fields at different assessment times in 2009 as determined by enzyme-linked immunosorbent assay (ELISA) and real-time reverse-transcription polymerase chain reaction (RT-PCR) assay

\begin{tabular}{|c|c|c|c|c|c|c|c|c|c|c|}
\hline \multirow[b]{5}{*}{ Cultivar, field } & \multicolumn{10}{|c|}{ Number of samples tested positive } \\
\hline & \multicolumn{9}{|c|}{ For given weeks ${ }^{a}$} & \multirow[b]{4}{*}{ Grower $^{d}$} \\
\hline & \multirow{3}{*}{$\begin{array}{c}\text { 22 June } \\
\text { Leaf } \\
\text { ELISA } \\
\end{array}$} & \multirow{2}{*}{\multicolumn{2}{|c|}{$\begin{array}{c}20 \text { July } \\
\text { Leaf }\end{array}$}} & \multicolumn{4}{|c|}{17 August } & \multirow{2}{*}{\multicolumn{2}{|c|}{$\begin{array}{c}\text { 6 September } \\
\text { Tuber }^{\mathrm{b}} \\
\end{array}$}} & \\
\hline & & & & \multicolumn{2}{|c|}{ Leaf } & \multicolumn{2}{|c|}{ Developing tuber ${ }^{\mathbf{b}}$} & & & \\
\hline & & ELISA & PCR & ELISA & PCR & PCR & Grow-out $^{\mathrm{c}}$ & PCR & Grow-out $^{\mathrm{c}}$ & \\
\hline Adirondack Red & $0(0)$ & 0 & 1 & 2 & 2 & 2 & 2 & 2 & 2 & $\ldots$ \\
\hline CalWhite field 1 & $3(2.5)$ & 1 & 1 & 6 & 6 & 8 & 8 & 21 & 20 & 11 \\
\hline CalWhite field 2 & $1(0.8)$ & 1 & 1 & 2 & 3 & 8 & 9 & 23 & 24 & 16 \\
\hline Goldrush field 1 & $0(0)$ & 0 & 0 & 2 & 2 & 7 & 8 & 20 & 19 & 5 \\
\hline Goldrush field 2 & $0(0)$ & 0 & 0 & 4 & 4 & 13 & 13 & 17 & 15 & 5 \\
\hline Innovator field 1 & $0(0)$ & 0 & 0 & 0 & 1 & 1 & 1 & 8 & 5 & 3 \\
\hline Innovator field 2 & $0(0)$ & 0 & 0 & 3 & 3 & 5 & 6 & 23 & 20 & 8 \\
\hline Russet Burbank field 1 & $1(0.8)$ & 1 & 2 & 2 & 2 & 9 & 9 & 12 & 13 & 7 \\
\hline Russet Burbank field 2 & $0(0)$ & 0 & 0 & 3 & 6 & 7 & 7 & 24 & 24 & 5 \\
\hline Shepody field 1 & $0(0)$ & 0 & 0 & 7 & 8 & 21 & 26 & 37 & 37 & 26 \\
\hline Shepody field 2 & $1(0.8)$ & 1 & 1 & 9 & 9 & 20 & 21 & 36 & 36 & 27 \\
\hline Mean & $1(0.8)$ & 0.4 & 0.6 & 3.6 & 4.2 & 9.2 & 10.0 & 20.3 & 19.6 & 11.3 \\
\hline
\end{tabular}

a In all, 120 plants were tested in each cultivar/field in the week of 22 June. Plants infected with PVY were discarded at this stage and only 100 healthy plants in each field were kept for subsequent assessments (week of 20 July, 17 August, and 6 September).

${ }^{b}$ Two tubers were used from each flagged plant.

${ }^{c}$ Tubers were grown-out in the greenhouse and foliage was used in ELISA.

${ }^{d}$ Number of samples tested positive out of 200 tubers submitted by growers; ELISA on sprouts. 


\section{Results}

Current-season spread of PVY in seed potato fields. PVY incidence in the fields in the week of 22 June (4 to 5 weeks after plant emergence) varied from 0 to $2.5 \%$ in 2009 and 0 to $5 \%$ in 2010 based on the ELISA test on leaf samples (Tables 1 and 2). Samples that tested positive were excluded from the study because these were most likely seedborne infections. These infected plants were rogued the week after by the growers. Of the 100 PVY-free plants selected from each field to monitor current-season spread during the growing season, the PVY incidence detected by ELISA was 0 to $1 \%$ in 2009 (Table 1) and 0 to $4 \%$ in 2010 (Table 2) by the week of 20 July. PVY incidence detected by real-time RT-PCR for the same assessment period was 0 to $2 \%$ in 2009 (Table 1) and 0 to $4 \%$ in 2010 (Table 2). No visible symptoms were observed by the week of 20 July in both years in the selected rows. By the week of 17 August, in PCR assays, PVY was detected in leaves from all fields in both years, except in the field cultivated with Adirondack Red in 2010. The highest PVY incidence for this assessment time in 2009 was 9\% (Shepody field 2) based on the leaf samples tested using both ELISA and real-time RT-PCR. The highest PVY incidence for the week of 17 August was 30\% (Goldrush field 2) in 2010 based on the leaf samples tested using real-time RT-PCR. However, the PVY incidence based on ELISA for the same leaf samples was $18 \%$ (Goldrush field 2). The highest PVY incidence for the week of 17 August based on developing tubers and detected by real-time RT-PCR was $21 \%$ (Shepody field 1) and $30 \%$ (Goldrush field 2) in 2009 and 2010, respectively. At the time of harvest, following top-kill, PVY incidence in tubers reached as high as $37 \%$ in 2009 and $39 \%$ in 2010 . At this time, a majority of the fields had a PVY incidence greater than $15 \%$ in both years. The results from the grow-out test based on the leaves were compared with the results from the harvested tubers. PVY incidence based on the grow-out tests conducted on the tubers collected in the weeks of 17 August and 6 September was very similar to PVY incidence detected by real-time RT-PCR for these assessment times. However, PVY incidence based on the tubers submitted by the growers to a CFIA-approved laboratory was generally lower than the PVY incidence detected by real-time RT-PCR at the time of harvest. The tubers submitted by the growers were randomly selected from the entire field whereas this study was conducted only in, at maximum, an area of approximately $8.5 \%$.

Predicting postharvest incidence of PVY based on preharvest testing of developing tubers. PVY incidence of the tubers at the time of harvest (week of 6 September) was generally higher in all fields than the incidence in developing tubers (week of $17 \mathrm{Au}$ gust) in both years (Tables 1 and 2). However, PVY incidence of developing tubers was a strong predictor of PVY incidence later in the season in both years. PVY incidence in developing tubers in August, assessed by real-time RT-PCR, was strongly predictive of PVY incidence in tubers at the time of harvest in September (2009: $\chi^{2}$ statistic $=44.89, \mathrm{df}=1, P<0.0001 ; 2010: \chi^{2}$ statistic $=38.90$, df $=1, P<.0001$ ), as well as PVY incidence observed with the grow-out test of the same tubers (leaf test by ELISA) (2009: $\chi^{2}$ statistic $=51.19, \mathrm{df}=1, P<0.0001 ; 2010: \chi^{2}$ statistic $=35.13, \mathrm{df}=$ $1, P<0.0001)$. Furthermore, a significant correlation was found between PVY incidence of developing tubers and PVY incidence at the time of harvest. The correlation coefficients $(r)$ were 0.824 (df $=9, P=0.002)$ and $0.802(\mathrm{df}=9, P=0.003$ ) for 2009 and 2010, respectively. These results indicate that postharvest PVY incidence can be estimated based on the PVY incidence of developing tubers.

Detection of PVY from leaves and dormant tubers using real-time RT-PCR. Real-time RT-PCR detected a higher number of PVY-positive samples from the leaves that were collected in the weeks of 20 July and 17 August compared with ELISA in both years as indicated by the mean PVY incidence for the two assessment periods (Tables 1 and 2). A higher number of positive samples was also detected with real-time RT-PCR from developing tubers compared with leaves collected from the same plants in the week of 17 August for most fields in 2009 and 2010.

The developing tubers collected in the week of 17 August and tested by real-time RT-PCR showed a mean PVY incidence of 9.2 and $14.0 \%$ in 2009 and 2010 , respectively. The grow-out test of the same tubers (leaf test by ELISA), showed a mean PVY incidence of 10.0 and $16.4 \%$ in 2009 and 2010, respectively. The results from real-time RT-PCR on tubers and grow-out tests were highly correlated in $2009(r=0.989$, df $=9, P=0.0001)$ and $2010(r=0.957, \mathrm{df}=9, P=0.0001)$. We found that real-time RTPCR of tuber tissue was a reliable indicator of PVY content of tubers at harvest.

\section{Discussion}

We have monitored PVY spread during the growing season in 11 fields scattered in the potato-growing areas of New Brunswick in 2009 and 2010. The majority of the fields evaluated had a PVY incidence greater than $15 \%$ in both years at the time of harvest. This indicates the challenge faced by the seed potato growers to

Table 2. Potato virus $Y$ (PVY) incidence (\%) in potato fields at different assessment times in 2010 as determined by enzyme-linked immunosorbent assay (ELISA) and real-time reverse-transcription polymerase chain reaction (RT-PCR) assay

\begin{tabular}{|c|c|c|c|c|c|c|c|c|c|c|}
\hline \multirow[b]{5}{*}{ Cultivar, field } & \multicolumn{10}{|c|}{ Number of samples tested positive } \\
\hline & \multicolumn{9}{|c|}{ For given weeks ${ }^{\mathbf{a}}$} & \multirow[b]{4}{*}{ Grower $^{d}$} \\
\hline & \multirow{3}{*}{$\begin{array}{c}\text { 22 June } \\
\text { Leaf } \\
\text { ELISA } \\
\end{array}$} & \multirow{2}{*}{\multicolumn{2}{|c|}{$\begin{array}{c}20 \text { July } \\
\text { Leaf }\end{array}$}} & \multicolumn{4}{|c|}{17 August } & \multirow{2}{*}{\multicolumn{2}{|c|}{$\begin{array}{c}\text { 6 September } \\
\text { Tuber }^{\mathrm{b}}\end{array}$}} & \\
\hline & & & & \multicolumn{2}{|c|}{ Leaf } & \multicolumn{2}{|c|}{ Developing tuber ${ }^{b}$} & & & \\
\hline & & ELISA & PCR & ELISA & PCR & PCR & Grow-out $^{c}$ & PCR & Grow-out $^{\mathrm{c}}$ & \\
\hline Adirondack Red & $6(5.0)$ & 0 & 0 & 0 & 0 & 2 & 2 & 18 & 19 & $\ldots$ \\
\hline CalWhite field 1 & $0(0)$ & 0 & 0 & 3 & 3 & 4 & 4 & 5 & 5 & 7 \\
\hline CalWhite field 2 & $2(1.6)$ & 1 & 1 & 4 & 5 & 9 & 9 & 20 & 34 & 16 \\
\hline Goldrush field 1 & $0(0)$ & 0 & 1 & 7 & 6 & 15 & 16 & 19 & 23 & 23 \\
\hline Goldrush field 2 & $2(1.6)$ & 4 & 4 & 18 & 30 & 30 & 39 & 39 & 39 & 25 \\
\hline Innovator field 1 & $5(4.1)$ & 2 & 2 & 14 & 19 & 19 & 20 & 20 & 26 & 18 \\
\hline Innovator field 2 & $1(0.8)$ & 1 & 3 & 18 & 27 & 26 & 26 & 37 & 37 & 25 \\
\hline Russet Burbank field 1 & $5(4.1)$ & 3 & 4 & 5 & 4 & 11 & 11 & 16 & 16 & 10 \\
\hline Russet Burbank field 2 & $6(5.0)$ & 1 & 2 & 2 & 2 & 7 & 7 & 13 & 12 & 9 \\
\hline Shepody field 1 & $3(2.5)$ & 1 & 1 & 11 & 12 & 19 & 25 & 22 & 34 & 20 \\
\hline Shepody field 2 & $2(1.6)$ & 3 & 4 & 13 & 12 & 12 & 21 & 32 & 40 & 22 \\
\hline Mean & $3(2.5)$ & 1.5 & 2.0 & 8.4 & 10.1 & 14.0 & 16.4 & 21.9 & 25.9 & 17.5 \\
\hline
\end{tabular}

${ }^{a}$ In all, 120 plants were tested in each cultivar/field in the week of 22 June. Plants infected with PVY were discarded at this stage and only 100 healthy plants in each field were kept for subsequent assessments (week of 20 July, 17 August, and 6 September).

${ }^{\mathrm{b}}$ Two tubers were used from each flagged plant.

${ }^{c}$ Tubers were grown-out in the greenhouse and foliage was used in ELISA.

d Number of samples tested positive out of 200 tubers submitted by growers; ELISA on sprouts. 
produce a crop with a low PVY incidence to target the seed markets. Seed lots with PVY incidence exceeding 1 to $3 \%$ are not usually certified and are unsuitable for seed purposes (8). The Canadian seed certification system is based on visual inspections of the growing crop, which may not be accurate, particularly in cultivars that do not express clear symptoms. In addition, PVY infections that begin later in the growing season usually do not produce visible symptoms and, thus, go undetected. Therefore, a reliable method is required to determine PVY incidence in the growing crop and tubers after harvest. Our study demonstrated that PVY incidence in a seed potato crop may increase from $0 \%$ at the time of planting to as high as $39 \%$ at the time of tuber harvest. It should be noted that we could not test tubers before planting to be certain that tubers were free of PVY. Nolte et al. (15) demonstrated that plots planted even with the healthy seed ( $0 \%$ PVY) showed a mean PVY incidence of $1.9 \%$ in Russet Burbank, $8.3 \%$ in 'Russet Norkotah', and $13.2 \%$ in Shepody at tuber harvest. In our study, there was a high variation in PVY incidence among fields in 2009 and 2010. This variation may be due to aphid pressure, cultivar selection, and crop management practices employed by the growers. Therefore, optimization of crop management practices through grower outreach activities, and supplementation of the seed certification system based on visual inspections of the growing crop with ELISA- and real-time RT-PCR-based assays, can be beneficial for PVY management in the region.

ELISA and different forms of PCR (RT-PCR and real-time RTPCR) have been used to detect PVY in leaves, sprouts, and dormant tubers $(1,14,18)$. However, only preliminary work had been conducted using RT-PCR methods to detect PVY in developing tubers (21). It is interesting that a higher number of positive samples was detected by real-time RT-PCR from developing tubers compared with leaves collected from the same plant at the same assessment time for most fields in 2009 and 2010. The higher PCR detection in developing tubers than in leaves of the same plant may be because tubers were a greater photosynthate (and, therefore, virus) sink than leaves at the time of testing. Mostly, plant viruses follow the routes of metabolites from source to sink tissues and, once it has entered into the sieve element, the infectious entity is passively transported to other (sink) plant parts (16). Results demonstrate that the real-time RT-PCR assay described here can reliably detect PVY from developing tubers. Because ELISA needs sprouting of dormant potato tubers for PVY testing, grow-out testing takes about 6 to 8 weeks to obtain results and conventional RT-PCR requires post-PCR processing; in contrast, real-time RTPCR can be completed in 2 to 3 days and, therefore, provides a quick alternative to detect PVY from developing or dormant tubers in a diagnostic laboratory (17). Therefore, this new application of real-time RT-PCR assay can be successfully used to monitor current-season spread of PVY.

PVY incidence in tubers at the time of harvesting was highly correlated with PVY incidence of developing tubers. The aphid pressure in the field from the time the developing tubers were tested and top-killed may influence the PVY incidence at the time of harvest. Future studies will investigate how aphid pressure influences the PVY incidence during this period. Preharvest testing provides another option to growers to either top-kill the crop immediately to secure the seed market when the PVY incidence is low or leave the tubers to develop further for table or processing purposes when incidence of PVY is high.

\section{Acknowledgments}

We thank Canada/New Brunswick Embracing Innovation in Agriculture and Agri-Food Program for funding; participating growers for providing field facilities; R. P. Singh for critical review of the manuscript; T. D. B. MacKenzie for statistical analyses; and A. Gallagher, M. Diotte, M. Hampsey, M. Filivosic, M. Pelletier, and H. Olsen for their technical help.

\section{Literature Cited}

1. Agindotan, B. O., Shiel, P. J., and Berger P. H. 2007. Simultaneous detection of potato viruses, PLRV, PVA, PVX and PVY from dormant tubers by TaqMan real-time RT-PCR. J. Virol. Methods 142:1-9.

2. Boiteau, G., Singh, M., and Lavoie, J. 2009. Crop border and mineral oil sprays used in combination as physical control methods of the aphid-transmitted potato virus $Y$ in potato. Pest Manage. Sci. 65:255-259.

3. Boonham, N., Walsh, K., Mumford, R. A, and Barker, I. 2000. Use of multiplex real-time PCR (TaqMan) for the detection of potato viruses. OEPP/ EPPO Bull. 34:427-430.

4. Bradley, R. H. E. 1954. Studies of the mechanism of transmission of potato virus Y by the green peach aphid, Myzus persicae (Sulz.). Can. J. Zool. 32:64-73.

5. Browning, I., Charlet, K., Chrzanowska, M., Dedic, P., Kerlan, C. Kryszcuk, A., Schubert, J., Varveri, C., Werkman, A., and. Wolf, I. 2004. What is PVYNTN? The reaction of potato cultivars to inoculation with a range of PVY isolates. Pages 48-50 in: Abstr. 12th EAPR Virol. Sect. Meet. Rennes, France. 13-19 June 2004.

6. Crosslin, J. M., Hamm, P. B., Hane, D. C., Jaeger J., Brown C. R., Shiel, P. J., Berger, P. H., and Thornton, R. E. 2006. The Occurrence of PVYO, $\mathrm{PVY}^{\mathrm{N}}$, and $\mathrm{PVY} \mathrm{N}^{\mathrm{N} O}$ strains of Potato virus $Y$ in certified potato seed lot trials in Washington and Oregon. Plant Dis. 90:102-1105.

7. Fox, A., Evans F., and Browning, I. 2005. Direct tuber testing for Potato $Y$ potyvirus by real-time RT-PCR and ELISA: reliable options for post-harvest testing? OEPP/EPPO Bull. 35:93-97.

8. Gray, S., De Boer, S., Lorenzen, J., Karasev, A., Whitworth, J., Nolte, P., Singh, R., Boucher, A., and $\mathrm{Xu}, \mathrm{H}$. 2010. Potato virus $Y$ : an evolving concern for potato crops in the United States and Canada. Plant Dis. 94:1384-1397.

9. Hansen, L. M., and Nielsen, S. L. 2012. Efficacy of mineral oil combined with insecticides for the control of aphid virus vectors to reduce potato virus Y infections in seed potatoes (Solanum tuberosum). Acta Agric. Scand. Sect. B Soil Plant Sci. 62:132-137.

10. Lorenzen, J. H., Piche, L., Gudmestad, N. C., Meacham, T. P. H., and Shiel, P. J. 2006. A multiplex PCR assay to characterize Potato virus Y isolates and identify strain mixtures. Plant Dis. 90:935-940.

11. MacDonald, J. G., and Coleman, W. K. 1984. Detection of potato viruses Y and $\mathrm{S}$ in tubers by ELISA after breaking of dormancy with bromoethane or rindite. Am. J. Potato Res. 61:619-622.

12. Nanayakkara, U. N., Singh, M., Pelletier, Y., and Nie, X. 2012. Investigation of Potato virus $Y$ (PVY) strain status and variant population in potatoes in New Brunswick, Canada., Am. J. Potato Res. 89:232-239.

13. Nie, B., Singh, M., Sullivan, A., Singh, R. P., Xie, C. H., and Nie, X. 2011. Recognition and molecular discrimination of severe and mild $\mathrm{PVY}^{\mathrm{O}}$ variants of Potato virus $Y$ in potatoes in New Brunswick, Canada. Plant Dis. 95(2):113-119.

14. Nie, X., and Singh, R. P. 2002. A new approach for the simultaneous differentiation of biological and geographical strains of Potato virus $Y$ by uniplex and multiplex RT-PCR. J. Virol. Methods 104:41-54.

15. Nolte, P., Whitworth, J. L., Thornton, M. K., and McIntosh, C. S. 2004 Effect of seedborne Potato virus $Y$ on performance of Russet Burbank, Russet Norkotah, and Shepody potato. Plant Dis. 88:248-252.

16. Silva, M. S., Wellink, J., Goldbach, R. W., and van Lent, J. W. M. 2002. Phloem loading and unloading of Cowpea mosaic virus in Vigna unguiculata. J. Gen. Virol. 83:1493-1504.

17. Singh, M., Singh, R. P., Fageria, M. S., Nie, X., Coffin, R., and Hawkins, G. 2012. Optimization of a real-time RT-PCR assay and its comparison with ELISA, conventional RT-PCR and the grow-out test for large scale diagnosis of Potato virus $Y$ in dormant potato tubers. Am. J. Potato Res. 90:43-50.

18. Singh, M., Singh, R. P., and Moore, L. 1999. Evaluation of NASH and RTPCR for the detection of PVY in dormant tubers and its comparison with visual symptoms and ELISA in plants. Am. J. Potato Res. 75:1-5.

19. Singh, R. P. 1998. Reverse-transcription polymerase chain reaction for the detection of viruses from plants and aphids. J. Virol. Methods 74:125-138.

20. Singh, R. P., McLaren, D. L., Nie, X., and Singh, M. 2003. Possible escape of a recombinant isolate of Potato virus $Y$ by serological indexing and methods of its detection. Plant Dis. 87:679-685.

21. Singh, R. P., Nie, X., Coffin, R., Burns, M., and Huestis, D. 2002. Determination of current season spread of Potato leaf roll virus (PLRV) and Potato virus $Y$ by RT-PCR and ELISA techniques. Pages 9-11 in: Proc. North-East Potato Technol. Forum, Fredericton, NB, Canada. 11-12 March 2002.

22. Wang, H, Chen, X.-P., and Qiu, F.-Z. 2004. Increased hepatic expression of nitric oxide synthase type II in cirrhotic rats. World $\mathrm{J}$ Gastroenterol. 10:1923-1927. 